\title{
Bacteriophages and their applications: general aspects and a new insight in Ethiopia
}

\author{
Dejen Nureye $^{1^{*}}$, Saladdin Mohammed ${ }^{1}$, Solomon Assefa ${ }^{2}$ \\ ${ }^{1}$ Department of Pharmacy, College of Medicine and Health Sciences, Mizan-Tepi University (Mizan Campus), P.0. Box 260, Mizan-Aman, \\ Ethiopia \\ 2Department of Pharmacology and Clinical Pharmacy, College of Health Sciences, School of Pharmacy, Addis Ababa University, P.O. Box \\ 1176, Addis Ababa, Ethiopia
}

\begin{abstract}
Bacteriophages, having a variety of function in different disciplines, are viruses that invade bacterial cells. Phages are enormously essential to the ecology and evolution of bacteria, and have huge impacts on global weather patterns. Due to their easiness to manipulate, they have been used in dissimilar types of genetic analysis and also implemented in hydrological tracing. Modified filamentous bacteriophages can be used in the production of nanodevices and as an agent in extraction of triacylglycerols. While their invention over a decade, they have been subjugated mainly to treat infections caused by bacteria. Phage therapy could become a welcome option in this era with a paucity of new antibiotic to battle against multi-drug resistant pathogens. This enemy of bacteria can also be used to combat antimicrobial resistance. This annotation is tried to touch the current progress in bacteriophage research and applications including biocontrols, diagnostic purposes, drug innovation and new drug delivery systems. Regarding efforts made in Ethiopia, there is limited study on isolation of phage and their therapeutic potential. Antibiotic resistance is of major community health concern in Ethiopia. Hence, the idea of using bacteriophage should be taken into consideration and health professionals should have to show inclination towards phage therapy. Moreover, substantial academic efforts have to be made before approval of phage utilization in Ethiopia.
\end{abstract}

Keywords: Bacteriophage, Antibiotic resistance, Pharmaceutical applications, Ethiopia

Article Info: Received 18 Oct, 2018; Review Completed 12 Nov 2018; Accepted 14 Nov 2018; Available online 15 Nov 2018

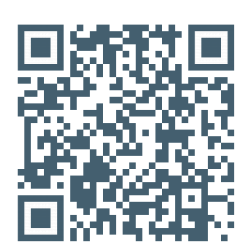

Cite this article as:

Nureye D, Mohammed S, Assefa S, Bacteriophages and its applications: general aspects, and a new insight in Ethiopia, Journal of Drug Delivery and Therapeutics. 2018; 8(6):278-284 DOI: http://dx.doi.org/10.22270/jddt.v8i6.2090

*Address for Correspondence:

Dejen Nureye, Department of Pharmacy, College of Medicine and Health Sciences, Mizan-Tepi University (Mizan Campus), P.O. Box 260, Mizan-Aman, Ethiopia

\section{INTRODUCTION}

Bacteriophages are bacterial viruses that assault bacterial cells and also disrupt bacterial metabolism and cause lysis or death of the bacteria ${ }^{1}$. This review provides introductory concepts and some contemporary advances concerning bacteriophage. It also gives detail on the extensive range of pharmaceutical applications of phages including diagnosis of diseases, its prevention and treatment. As an intracellular organism, they are found everywhere where their bacterial host is present. These microscopic parasites are the most ever-present in nature and play a major role in maintaining microbial balance on this planet ${ }^{2}$. Bacteriophages (phages) can easily be isolated or obtained from their natural foundation such as water, soil, sewage, fermented product and unprocessed vegetables following standard procedure ${ }^{3}$. More than 6000 different phages have been discovered and described morphologically ${ }^{4}$. However, fewer than 1,500 complete phage genomes were listed in GenBank, many of which have not been studied experimentally5.

Bacteriophages must infect a host bacterial cell with the appropriate receptors in the outer membrane in order to replicate themselves ${ }^{6}$. The steps that form the course of infection are collectively known as phage life cycle: lytic, lysogenic, pseudo-lysogenic, and chronic infection. Some of them can only reproduce through a lytic life cycle, in which they rupture and slay their host cells (figure 1a). Others can alternate between a lytic and lysogenic life cycle as shown in figure $1 \mathrm{~b}$, in which they do not destroy the host cell instead copied along with the host DNA as the cell divides?. 


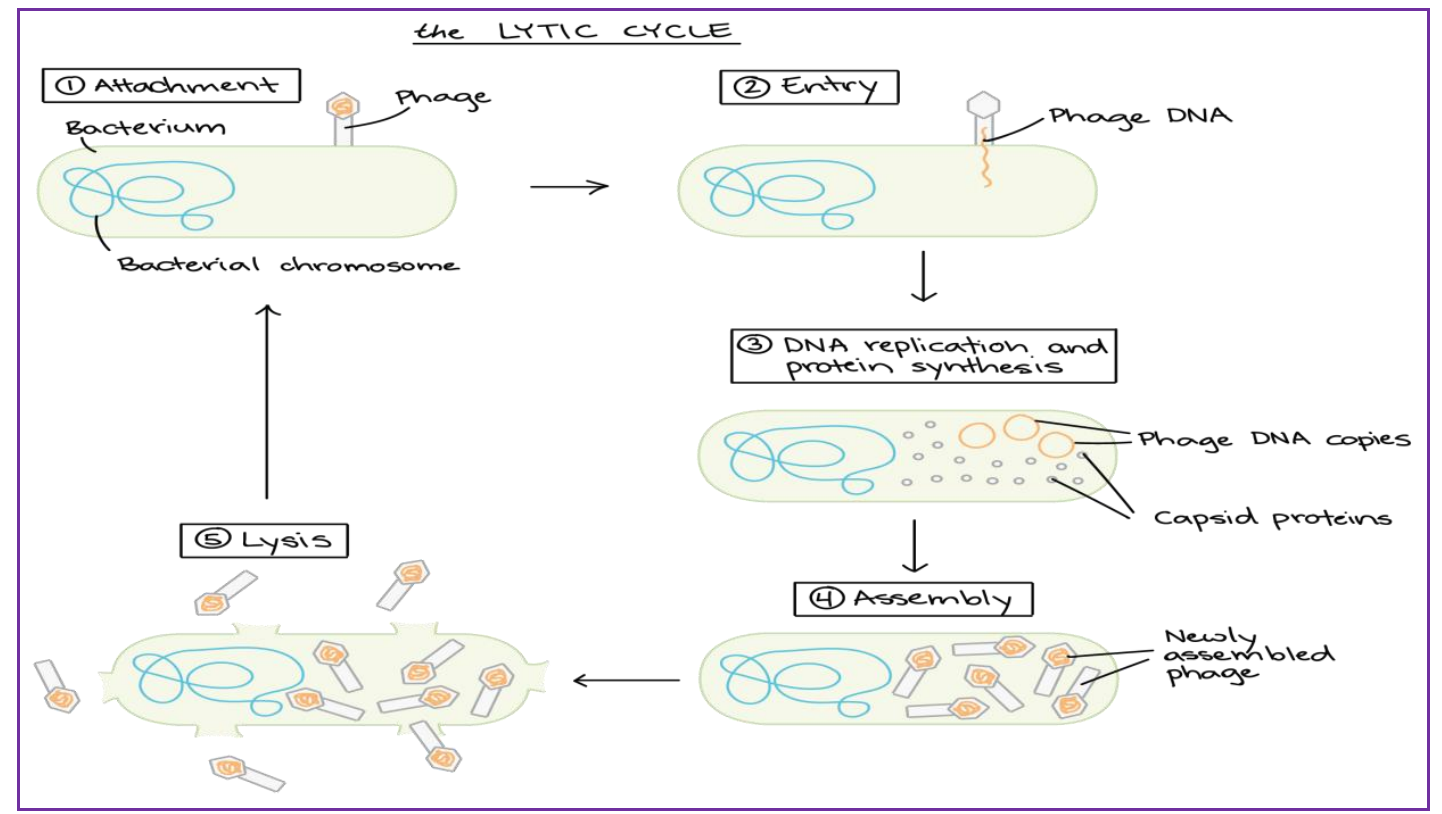

Figure1a: Lytic cycle of bacteriophage ${ }^{7}$

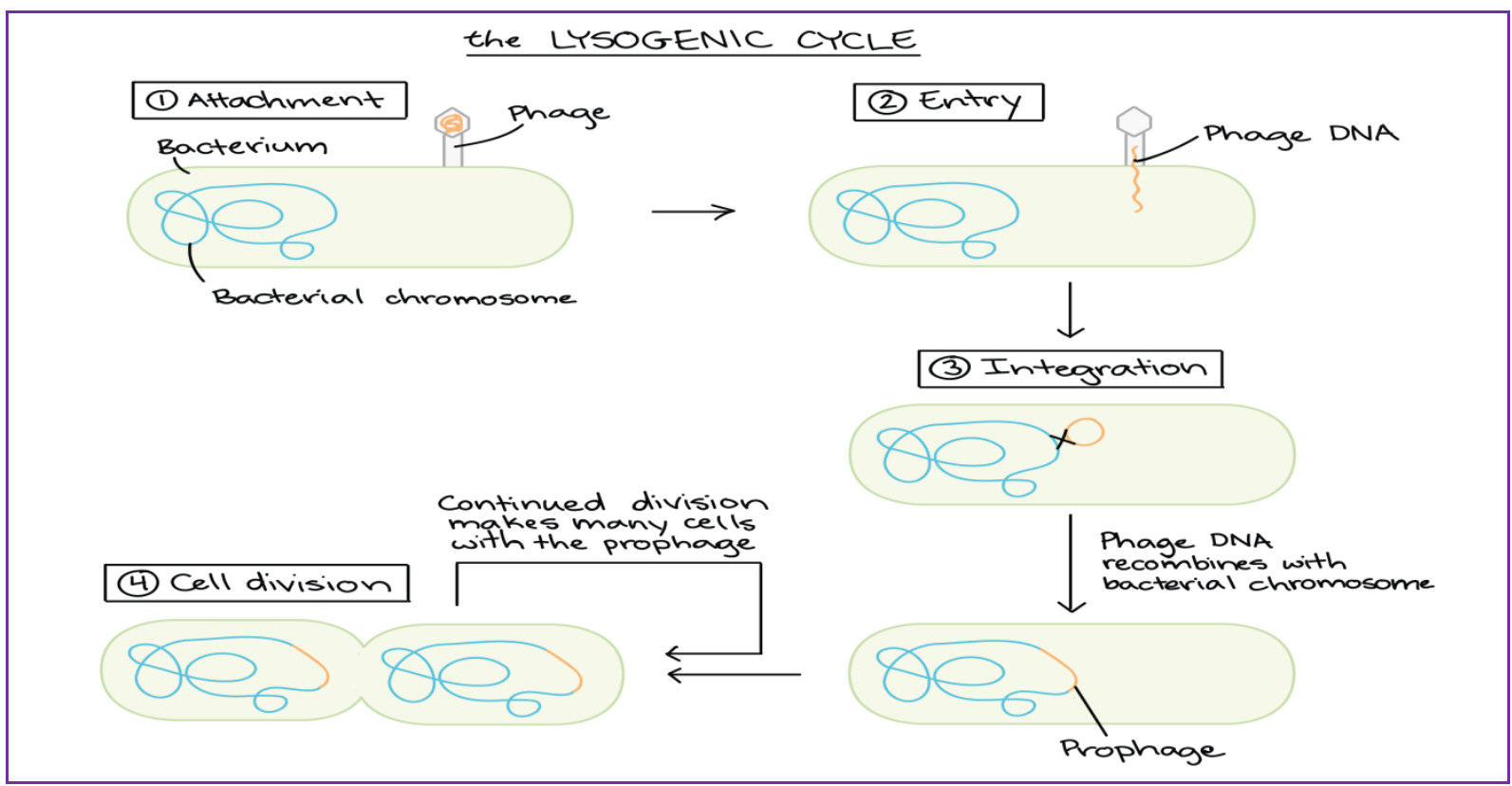

Figure1b: Lysogenic cycle of bacteriophage ${ }^{7}$

\section{Contemporary Advances and Novel Applications}

Bacteriophages are tremendously important to the ecosystem and evolution of bacteria ${ }^{8}$. As one of viruses that literally prey on bacteria, phage fills a rapacious role in their native ecology. Predators help keep prey populations in check, in turn preventing exhaustion of available resources ${ }^{9}$. They are the most copious virus in the ocean. A group of phage which is called as pelagiphages infects and destroys SAR11 bacteria that change dissolved carbon molecules into carbon dioxide and influence the quantity of available atmospheric carbon. Hence, phages have enormous impacts on the global carbon cycle ${ }^{10}$. It is estimated that bacteriophages lyse and eradicate between 15 and $40 \%$ of the ocean's bacteria every day, thereby influencing the ratio of particulate to dissolved carbon, rates of phytoplankton productivity and oxygen production, and perhaps even global weather patterns ${ }^{5,11}$.
Recently, Jennifer Brum ${ }^{9}$ hypothesized that the recycling of micronutrients and components of cells such as amino acids and nucleic acids has been linked to bacterial lysis by phage(s). This likely form a clogged loop in nearly all environments where actively growing bacteria use resources scavenged from the deceased. The aggregation of lysed cells, however, may result in large particles that sink in the ocean, contributing to the presence of core protein clusters in aphotic zones. This same sedimentation carries the organic matter away from microbes in the photic zones hence, forcing increased use of atmospheric carbon dioxide to generate more biomass ${ }^{9}$. The release of phage induced lysis products changes organic carbon from particulate to dissolved forms, which makes organic carbon more bio-available and thus acts as a catalyst of geochemical nutrient cycles ${ }^{12}$. 
Besides their role in the ecological unit, phages can be used in a range of genetic analysis and they were the key to the development of genetic engineering8,13. Phages are thought to extensively contribute to horizontal gene transfer in natural surroundings, predominantly through transduction ${ }^{14}$. Of course, they are helpful in the genetic and metabolic diversity of their prey by transduction and modification of biochemistry during the infection process, respectively 9 .

Phages are also implemented in hydrological tracing plus modeling in river systems, particularly at a place where groundwater and surface water interacts ${ }^{15}$. They fulfill various requirements of the ideal indicators of pathogenic contamination. These features contribute to the usefulness of phages as surrogates for the fate and transport of microbial pathogens of health concern in source and drinking waters, with particular reference to: (a) indicating the existence of enteric viruses in natural waters, (b) contributing to microbial source tracking, (c) evaluating the effectiveness of water treatment processes, and (d) elucidating the mechanisms involved in the fate and transport of enteric viruses in natural or engineered filtration media 6 .

Genetic modifications of filamentous phages enable us to use bacteriophages in the development of material to construct films and nanowires in favor of semiconductor applications, piezoelectric energy production, and photoresponsive behaviours ${ }^{16}, 17,18$. These materials are also being used to make devices like ion batteries and catalysts, and to let guided cell growth for human tissue formation ${ }^{19}, 20$, 21. Bacteriophage RNA polymerase as well as ribonuclease $\mathrm{H}$ has been used to form in vitro genetic circuits that have potential future appliance in nanodevices and regulation of processes inside artificial cells $^{22}$. These enzymes are also used to make novel apparatus for bacterial genome editing and accelerated evolution ${ }^{23,24}$. Phage Toil has a potential to be a new tool for the development of cost effective and bio-friendly methods for extraction of triacylglycerols from oleaginous bacterium Rhodococcus opacus. Additionally, Phage Toil can be a new model phage to advance knowledge regarding phage infection mechanisms in Rhodococcus and other mycolic acid-containing bacteria ${ }^{25}$.

\section{Pharmaceutical Applications}

After discovery in 1915 by Twort'26, phages were initially used to manage bacterial infections, even if there was no widespread acceptance owing to lack of understanding of its biology as well as the development of antibiotic in 1940s. For instance, they have been used as a treatment against pathogens such as Shigella dysenteriae as early as $1919^{2}$.

Notwithstanding the call for the discovery of novel antibiotics in the European Union and in the United States, there is shortage of innovative antibiotics in the developmental pipeline. Hence, the re-deployment of phage treatment could become an amenable option to antimicrobial drugs in this period of progressive spread of multi-drug resistant (MDR) and biofilm forming bacterial pathogens with a dearth of latest antibiotic to combat these microbes ${ }^{2}$. Lytic phages are alike to antibiotics in that they have remarkable antibacterial activity. However, therapeutic phages have some at least theoretical merits over antibiotics ${ }^{27}$.
Bacteriophages have been reported to be more effective than antibiotics in treating certain infections $28,29,30$. They are ecological friendly and are isolated and identified based on natural selection on bacteria in a very rapid process compared to new antibiotic development, which may take several years that cost millions of dollars for clinical trials ${ }^{31}$. Production of bacteriophage is simple unlike the complex and expensive production of antibiotic. The initial dose of phage therapy increases exponentially if the susceptible bacterial host is available. In such cases, there is no need to administer the phages repeatedly, however; a repeated dose of antibiotic is required to cure the bacterial disease ${ }^{32}$. No side effects have been reported during or after phage application ${ }^{27}$, but intestinal disorders, allergies sometimes even fatal anaphylactic reaction and secondary infections are some of the side effects of antibiotics ${ }^{33}$.

Target range is also one of the main differences between phages and antibiotics. Phages are very specific and they will normally only lyse strains of one species or a subset of strains within a species, it allow targeting of specific microbes without disrupting desirable bacterial flora 27,34 . Bacteriophages duplicate at the site of infection where they are mostly desired, but antibiotics travel throughout the body and do not concentrate at the site of infection ${ }^{27}$, 35,36 . Phages are self replicating as well as self-limiting. These living drugs are quickly flushed from the body and/or inactivated by the immune system when their host is no longer present ${ }^{37,38}$. Several studies reported that the combined use of phages and antibiotics improved the outcome of therapy ${ }^{27}$. By combined usage of bacteriophages and antibiotics, treatment has shown a promising: reduction in the amount of bacteria evolving to develop antibiotic resistance and increase in the reduction of bacterial infection $39,40,41$.

Phages can be used to combat antibiotic resistance through insertion or transfer of susceptible genes back into the bacterial genome. This allows bacteria that were once antibiotic resistant to regain susceptibility to antibiotics. This occurs because the genes that are transferred into the bacterium increase the permeability of its cell membrane and allow medications to pass through it more freely ${ }^{42}$. In fact, phages have been modified to transport clustered regularly interspaced short palindromic repeats (CRISPR)-Cas nucleases into antibiotic-resistant bacteria. In doing so, researchers are going to exploit the specific DNA-cleaving capacity of CRISPRs to knock out resistance sequences, rendering resistant organisms an antibiotic sensitive ${ }^{43}$.

Experiment is being conducted to devise a technique to clean hospital surfaces while treating resistant bacteria using phages ${ }^{42}$. It is now also used to improve the shelflife of meats, vegetables, fruits and stored plant parts 44 . Researchers have been exploit bacteriophages to counteract bioweapons as well as toxins, such as anthrax and botulism ${ }^{45}$. In addition to these, studies have been revealed the effectiveness of phages in averting the destruction of skin grafts by Peudomona aeruginosa ${ }^{46,47}$. A few research groups are also engineering phages for Methicillin-resistant Staphylococcus aureus treatments in variety of forms, including phage-impregnated sutures and wound dressings ${ }^{48}$. Furthermore, current findings on bacteriophages are summarized below (Table 1). 
Table 1: Summary of recent findings on phages related to therapy

\begin{tabular}{|c|c|c|c|c|}
\hline No. & Findings & $\begin{array}{l}\text { Phage(s) name } \\
\text { used in the study }\end{array}$ & Model & Ref. \\
\hline 1 & $\begin{array}{l}\text { Demonstrate that six lysins belonging to two different families are } \\
\text { active against a panel of enteropathogenic } C \text {. perfringens strains under } \\
\text { salinity and acidity conditions relevant to food preparation } \\
\text { environments and also demonstrate that plant-expressed lysins prevent } \\
\text { multiplication of } C \text {. perfringens on cooked meat matrices far better than } \\
\text { nisin, the only currently approved bacteriocin food preservative to } \\
\text { control this pathogen. }\end{array}$ & $\begin{array}{l}\text { phiSM101, } \\
\text { vB_CpeS-CP51, } \\
\text { phiCP26CPE, } \\
\text { str.4969F, and } \\
\text { phiCP39-0 }\end{array}$ & $\begin{array}{l}\text { In vitro } \\
\text { assay }\end{array}$ & 49 \\
\hline 2 & Isolated a phage that might be used for pathogenic E. coli control. & vB_EcoS_HSE2 & $\begin{array}{l}\text { In vitro } \\
\text { assay }\end{array}$ & 50 \\
\hline 3 & $\begin{array}{l}\text { Defines a role for circulating metals as a major factor that is essential } \\
\text { for the phage-based killing of bacteria in blood. }\end{array}$ & HP3, EC1, and CF2 & Mice model & 51 \\
\hline 4 & $\begin{array}{l}\text { Support the idea that phage endolysins are promising candidates for } \\
\text { developing therapeutics against anthrax infection. }\end{array}$ & $\begin{array}{l}\text { phage endolysins } \\
\text { (AP50-31 and } \\
\text { LysB4) }\end{array}$ & $\begin{array}{l}\text { In vitro \& in } \\
\text { vivo assays }\end{array}$ & 52 \\
\hline 5 & $\begin{array}{l}\text { Provide novel insights into the role of bacteriophages as potentially } \\
\text { pathogenic for mammals and their possible implication in the } \\
\text { development of diseases associated with increased intestinal } \\
\text { permeability. }\end{array}$ & $\begin{array}{l}\text { Salmonella phage } \\
\text { cocktail, } \\
\text { Pyobacteriophage }\end{array}$ & Rat model & 53 \\
\hline 6 & $\begin{array}{l}\text { The bacteriophages isolated from sewage demonstrated lytic efficacy } \\
\text { against MDR-bacterial isolates from septic wounds (P. aeruginosa, } S \text {. } \\
\text { aureus, K. pneumoniae and E. coli). }\end{array}$ & $\begin{array}{l}\text { PA DP4, KP DP1, } \\
\text { SA DP1, and EC } \\
\text { DP3 }\end{array}$ & $\begin{array}{l}\text { In vitro } \\
\text { assay }\end{array}$ & 54 \\
\hline 7 & $\begin{array}{l}\text { Described a preliminary strategy for effective attenuation of Serratia } \\
\text { growth during fish spoilage. }\end{array}$ & AZT1 up to AZT9 & In vitro test & 55 \\
\hline 8 & $\begin{array}{l}\text { Suggest opportunities for engineering } E \text {. faecalis phages that } \\
\text { circumvent the problem of bacterial phage resistance. }\end{array}$ & $\begin{array}{l}\text { E. faecalis V583, } \\
\varphi \mathrm{VPE} 25, \varphi \mathrm{VFW}\end{array}$ & In vivo assay & 56 \\
\hline 9 & $\begin{array}{l}\text { Demonstrated the activity of bacteriophage preparations that are used } \\
\text { as a part of standard clinical practice in the Republic of Georgia, against } \\
\text { MDR ESBL-EC isolated from Turkish patients. }\end{array}$ & $\begin{array}{l}\text { four cocktails } \\
\text { (Enko-phage, SES-, } \\
\text { Pyo-, and Intesti- } \\
\text { bacteriophage) }\end{array}$ & $\begin{array}{l}\text { In vitro spot } \\
\text { tests }\end{array}$ & 57 \\
\hline 10 & $\begin{array}{l}\text { Highlights the effectiveness of the phage therapy and provides further } \\
\text { insight into treating infections caused by MDR strains (Acinetobacter } \\
\text { baumannii) using phage administration. }\end{array}$ & vB-GEC_Ab-M-G7 & $\begin{array}{l}\text { Rat wound } \\
\text { model }\end{array}$ & 58 \\
\hline
\end{tabular}

Enzybiotics, a new development at Rockefeller University, generate enzymes from bacteriophage. As an enzybiotic, a purified recombinant phage enzyme could be used as separate antibacterial agents in their own right 59 . Direct use of phage encoded proteins such as endolysins, exopolysaccharidases and holins have shown their ability as a potential alternative to antibacterial agents ${ }^{2}$. Phage hyaluronidase can be exploited in suppressing hyaluronanmediated tumor growth and progression ${ }^{60}$. Both phages and encoded proteins of phages are used for specific identification and detection of bacteria which is reviewed in 61 . Reporter phage assays have been adapted to evaluate drug sensitivity in the target bacterium ${ }^{62}$.

Bacteriophages are in use for phage display. Phage display has a lot of applications in various molecular techniques: in new phage development, in purifying antibody or specific protein, epitopes mapping during vaccine design, specificity determination for enzymes and inhibitors, and screening receptors as well as anticancer peptide 63,64 .

They could also be employed as drug delivery system. Phages are used in two ways as vehicles for vaccine delivery, first directly in bearing vaccine antigens display on their surfaces and second in incorporating the gene or sequences that synthesized vaccine antigen in to the phage genome in DNA vaccine ${ }^{64}$. Bacteriophages can act as a carrier for antibacterial drugs, which are either attached to its surface or incorporated into the phage. The obvious advantage is that non-specific antibiotics for example chloramphenicol (not frequently used due to its hemolytic adverse effects) can be employed owing to a target specific action at the localized place of infection. In contrast to the free drug, superior efficiency and enhanced solubility were noted 65,66 . Bacteriophage targeted delivery of light sensitive antibiotics is another approach similar to the above principle. This procedure along with subsequent irradiation with red light resulted in a much greater eradication of Staphylococcus aureus isolates than either the phage or light-exposed photosensitizers alone. Targeting creates favorable condition to use low concentration and light doses so that the adverse effects were minimized 67 .

Phage coat protein-based vehicles are also being developed by anchoring drug-loaded liposomes to capsid proteins displaying peptides with binding specificity to a meticulous target ${ }^{68}$. Moreover, the application of phages to deliver anticancer drugs to a particular target has been illustrated in preliminary in vitro experiments 69 . Bacteriophages having an affinity to specific cell receptors, like those over expressed in cancer cells, may be subjugated further than drug delivery to let for concurrent target detection by displaying diagnostic reporter molecules or by detection of bound phage DNA by real-time PCR ${ }^{70,71}$.

Bacteriophages can be employed as specific gene delivery vectors. The foreign proteins expressed on the surface of phage enable them targeting specific cell types and after injection, phage capsid protein save DNA from degradation, which is a prerequisite for successful gene therapy ${ }^{42}$. Phage-capsids have been modified to provide the liberation of encapsulated RNA-guided endonucleases to specific cell types for in situ genome editing ${ }^{72,73}$. 


\section{Efforts Made in Ethiopia Regarding Bacteriophages}

In Ethiopia, Rhodobacteraceae were revealed to be one of the dominant families in the majority of soda lakes (Bogoria, Lonar, Zabuye and Kauhako), and the most diverse Family in Ethiopian soda lakes ${ }^{74}$. Van Zyl et al., (2016) has described a highly novel Paracoccus infecting virus (Shpa) identified from Lake Shala which jointly with NgoF6 and vB_PmaS_IMEP1 is one of only three phages known to infect Paracoccus species but does not show resemblance to this phages ${ }^{75}$. Generally, there is limited study on phage isolation and their therapeutic potential, particularly, against multi-drug resistant pathogen in Ethiopia. However, bacteriophage having ability of lysing MDR Escherichia coli was isolated and demonstrated by Getachew and his co-worker ${ }^{76}$. Moreover, very few review articles on phages, which are done by some universities from Ethiopia, were existed in scientific journals77, 78 . Efforts made in Ethiopia are specifically paying attention on isolation of bacteriophages from natural sources.

\section{A New Insight in Ethiopia}

According to Ethiopian Food, Medicine, Healthcare Administration and Control Authority (FMHACA), antimicrobial misuse together with quick spread of resistant microorganisms and non-strong surveillance has make worse the situation of antimicrobial resistance (AMR) in Ethiopia. Antibiotic resistance is of major community health concern in Ethiopia and reached a stage where many patients are unable to recover from infections ${ }^{79}$.

Even though extensive studies on AMR in Ethiopia have not yet been done, the available reports indicate a tendency towards increasing resistance rates among pathogens such as Escherichia coli, Staphylococcus aureus, Shigella spp., and Salmonella spp. to commonly prescribed antimicrobials including ampicillin, amoxicillin, penicillin, tetracycline and cotrimoxazole $^{80}$. Studies done in Addis Ababa revealed that serotypes of Salmonella were identified in supermarket meat and dairy samples and significant proportion have developed resistance for routinely prescribed antibiotics ${ }^{81}$, 82 .

Given the harshness of infection due to bacteria, and the multifaceted crisis presented by AMR in Ethiopia, it is believed that the phage notion should be taken into consideration as a precious tool to resolve the existing circumstances ${ }^{78}$. Phage remedy might be an alternative at least in certain cases. So, like Western medical professionals, health professionals in Ethiopia must have increased interest towards researches on phage therapy in order to fight against resistant and seriously intimidating infections ${ }^{83}$.

Non-human applications of phages may signify the widest use of these agents, which include use in veterinary, agriculture, and food hygiene and food safety78. Their benefit could be larger if phage products are accessible in developing countries, For instance, given the shortage of dependable refrigeration in many lower income countries like Ethiopia, meat products are preferably sold within twenty four hours of butcher. Thus, any antibacterial agent that could augment the shelf life even by one day possibly will have significant impacts not only on the health of community, but also on profitability for meat seller ${ }^{84}$.

Studies have verified that Campylobacter is inhabitant in the gastrointestinal tracts of up to $75 \%$ of poultry in many countries ${ }^{85}$. Thus, bacteriophages could be utilized to reduce bacterial loads in animals before they arrive at butcher houses ${ }^{84}$. Agriculture is among the vital economic sectors in Ethiopia and bacterial infections that were more difficult to control secondary to bactericide resistance are the main intimidation to agricultural production of food. Bacteriophage could be one of the biological control measures that destroy phytopathogens and lessen antibiotic and pesticide use thereby reduce the development of AMR.

The country is required in creating proper authoritarian guiding principle in advance of completely realizing the deployment of phages to improve the health of the community. As it is a novel idea, phages are hurdles that cause fear and misunderstanding. Therefore, we have to elucidate illusions and increase the praise of this most recent class of antimicrobial agents. Facilitating and organizing workshops as well as training to provide information concerning the possible use of bacteriophages, deal with safety issues, and get input on how phages could be properly applied in Ethiopia ${ }^{78}$. Additionally, our academia can exhaustively extract knowledge and practice regarding different aspects of bacteriophage from certain international non-governmental organizations of professionals which participate in projects, publication and education, and organize conference and presentations. For example, Phages for Global Health offers laboratory training workshops, teaching scientists in third world countries about phage biology where the necessity for alternatives to antibiotics is felt especially. In fact, the second East African Phage Workshop was held at Pwani University in Kilifi, Kenya. The trainees were learning how to isolate and characterize bacteriophages as antibiotic alternatives for use against resistant bacteria ${ }^{83,84}$.

Ethiopia has become a pharmaceutical manufacturing hub in Africa ${ }^{86}$. This occasion may create a favorable ground in isolating bacteriophage, manufacturing and commercialization of phage products. In support of this, product development projects are performed by Phages for Global Health in which international multidisciplinary teams are assembled that co-develop products from phage for specific applications in third world countries ${ }^{87}$. Phage holds a great potential and it should be exploited in Ethiopia, and thus collection of bacteriophages from environmental samples that have activity against a variety of bacterial hosts should be encouraged. Then after, plausible investigations must be done to assemble the necessary information with respect to the welfare and efficacy of phage therapy and evolutionary outcomes of its application ${ }^{78}$.

\section{CONCLUSION}

Phages are bacterial viruses which can simply be manipulated and have potential uses in research, biotechnology, and therapeutics. Increased threat of antibiotic resistance makes a great need of new antibacterial compounds and search for safe substitutes. Related to this context, phage therapy is more and more deemed to be a potential alternative. Phages have been employed as carriers for drugs as well vaccines, and as display systems for many proteins and antibodies. Efforts made in Ethiopia about phages are focused on a preliminary isolation from natural sources. Given the complicated problem presented by antimicrobial resistance in Ethiopia, health professionals have to show signs of increased interest towards phage therapy.

Conflict of Interest: The authors declare that there is no conflict of interests regarding the publication of this paper.

Acknowledgements: Not applicable 


\section{REFERENCES}

1. Abhilash M, Vidya A, Jagadevi T, Bacteriophage Therapy: A War Against Antibiotic Resistant Bacteria, The Internet Journal of Alternative Medicine, 2008; 7(1):1-5.

2. Xavier wittebole, Sophie De Roock, Steven M Opal, A historical overview of bacteriophage therapy as an alternative to antibiotics for the treatment of bacterial pathogens, Virulence, 2014; 5(1):226-235.

3. Pelzek AJ, Schuch R, Schmitz JE, Fischetti VA, Isolation, culture, and characterization of bacteriophages, Current Protocols Essential Laboratory Techniques, 2013; 4(4.4):4.4.1-4.4.33.

4. Ackermann HW, Prangishvili D, Prokaryote viruses studied by electron microscopy, Arch Virol, 2012; 157:1843-9.

5. Keen, Eric C., A century of phage research: Bacteriophages and the shaping of modern biology: Cause to reflect, BioEssays, 2015; 37(1):6-9.

6. Ipek Kurtböke, Bacteriophages. InTech; Janeza Trdine 9, 51000 Rijeka, Croatia, 2012, ISBN 978-953-51-0272-4. www.library.umac.mo.

7. KHANACADEMY, Bacteriophages. Bacteria-infecting viruses. The lytic and lysogenic cycles, 2018. www.khanacademy.org.

8. Stephen T. Abedon, Introduction to Bacteriophages, 2016. Phage-therapy.org

9. Ada Hagan, Bacteriophage: A Drop In The Carbon Ocean. American Society for Microbiology, 2016. www.asm.org.

10. Regina Bailey, 7 Facts About Bacteriophages, 2018. www.biology.about.com

11. Danovaro R, Corinaldesi C, dell'Anno A, Fuhrman J et al., Marine viruses and global climate change. FEMS Microbiol Rev., 2011; 35:993-1034.

12. Markus G. Weinbauer, Martin Agis, Osana Bonilla-Findji, Andrea Malits, Christian Winter, Bacteriophage: Genetics and Molecular Biology (Edited by: Stephen Mc Grath and Douwe van Sinderen). Caister Academic Press, U.K., 2007; pp, 61. www.about.qkport.com.

13. Anthony JF Griffiths, William M Gelbart, Jeffrey $\mathrm{H}$ Miller, Richard C Lewontin, Modern Genetic Analysis. W. H. Freeman, 1999, ISBN-10: 0-7167-3118-5.

14. Keen Eric C. et al., Novel "Superspreader" Bacteriophages Promote Horizontal Gene Transfer by Transformation, MBio., 2017; 8(1):e02115-16.

15. Martin C., The Application of Bacteriophage Tracer Techniques in South West Water. Water and Environment Journal, 1988; 2(6):638-642. www.about.qkport.com.

16. Mao C, Flynn CE, Hayhurst A, et al., Viral assembly of oriented quantum dot nanowires. Proc Natl Acad Sci U S A., 2003; 100(12):6946-51.

17. Lee BY, Zhang J, Zueger C, et al., Virus-based piezoelectric energy generation. Nat Nanotechnol, 2012; 7(6):351-6.

18. Murugesan M, Abbineni G, Nimmo SL, et al., Virus-based photo-responsive nanowires formed by linking site-directed mutagenesis and chemical reaction, Sci Rep., 2013; 3:1820. www.f1000research.com.

19. Lee Y, Kim J, Yun DS, et al., Virus-templated $\mathrm{Au}$ and $\mathrm{Au} / \mathrm{Pt}$ Core/shell Nanowires and Their Electrocatalytic Activitives for Fuel Cell Applications. Energy Environ Sci., 2012; 5(8):8328-34. www.f1000research.com.

20. Nam KT, Kim D, Yoo PJ, et al., Virus-enabled synthesis and assembly of nanowires for lithium ion battery electrodes, Science, 2006; 312(5775):885-8. 42.

21. Yoo SY, Chung W, Kim TH, et al., Facile patterning of genetically engineered M13 bacteriophage for directional growth of human fibroblast cells, Soft Matter, 2011; $7(2): 363-8$.

22. Kim J, Winfree E, Synthetic in vitro transcriptional oscillators. Mol Syst Biol., 2011; 7:465. www.f1000research.com.

23. Enyeart PJ, Chirieleison SM, Dao MN, et al., Generalized bacterial genome editing using mobile group II introns and Cre-lox, Mol Syst Biol., 2013; 9:685.

24. Esvelt KM, Carlson JC, Liu DR: A system for the continuous directed evolution of biomolecules, Nature, 2011; 472(7344):499-503.

25. Jason J. Gill1, Baixin Wang, Emily Sestak, Ryland Young, Kung-Hui Chu, Characterization of a Novel Tectivirus Phage
Toil and Its Potential as an Agent for Biolipid Extraction, Scientific Reports, 2018; 8:1062.

26. Twort FW, An investigation on the nature of ultramicroscopic viruses, Lancet 1915; 186:1241-3.

27. Sulakvelidze Alexander, Zemphira Alavidze, AND J. Glenn Morris, JR., Bacteriophage Therapy, Antimicrobial Agents And Chemotherapy, 2001; 45(3):649-659.

28. Zaman, G., A. Smetsers, A. Kaan, J. Schoenmaters, R. Konings, Regulation of expression of the genome of bacteriophage M13: Gene $V$ protein regulated translation of the mRNAs encoded by genes I, II, V and X, Biochimica et Biophysica Acta, 1991, 1089:183-192.

29. Young R, Bacteriophage lysis: mechanism and regulation. Microbiology and Molecular Biology Reviews, 1992; 56:430481.

30. Marza J., J. Soothill, P. Boydell T. Collyns, Multiplication of therapeutically administered bacteriophages in Pseudomonas aeruginosa infected patients, Burns, 2006; 32:644-646.

31. Weber-Dabrowska, B., M. Mulczyk, A. Gorski, Bacteriophage therapy of bacterial infections: an update of our institute's experience. Arch Immunol Ther Exp (Warsz), 2000; 48:547551. www.pdfs.semanticscholar.org.

32. Kumari, S., K. Harjai, S. Chhibber, Bacteriophage versus antimicrobial agents for the treatment of murine burn wound infection caused by Klebsiella pneumoniae B5055. Journal of Medical Microbiology, 2011; 60:205-210.

33. Yao J. D. C., and Moellering RC, Jr., Antimicrobial agents, 1995; p. 1474-1504. In P. R. Murray, E. J. Baron, M. A. P faller, F. C. Tenover, and R. H. Yolken (ed.), Manual of clinical microbiology, 7th ed. American Society for Microbiology, Washington, D.C.

34. Ayalew N and Ejo M, Review on Bacteriophages and its Antimicrobial Uses. Am-Euras. J. Sci. Res., 2016, 11(3):199208.

35. Smith H. W., Huggins MB, Successful treatment of experimental Escherichia coli infections in mice using phages: its general superiorityover antibiotics, J. Gen. Microbiol., 1982; 128:307-318.

36. Borysowski J.,Międzybrodzki R., and Górski A., Phage Therapy, Current Research and Applications, 2014; Pp.6.

37. Goodridge D., Designing phage therapeutics. Curr. Pharm Biotechnol., 2010; 11:15-27.

38. Elizabeth Kutter, Daniel De Vos, Guram Gvasalia, Zemphira Alavidze, Lasha Gogokhia, Sarah Kuhl and Stephen T. Abedon, Phage Therapy in Clinical Practice: Treatment of Human Infections. Current Pharmaceutical Biotechnology, 2010; 11:69-86.

39. Sakandelidze V.M., The combined use of specific phages and antibiotics in different infectious allergoses, Vrach. Delo, 1991; 3:60-63

40. Matsuzaki S., M. Rashel J. Uchiyma T. Ujihara, et al, Bacteriophage therapy: a revitalized therapy against bacterial infectious diseases. Journal of Infection and Chemotherapy, 2005; 11:211-219.

41. Casto A., Hurwitz A., Kou K., et al., Bacteriophages: The answer to antibiotic resistance? James Madison Undergraduate Research Journal, 2016; 3(1):36-41.

42. Viertel T. M., Ritter K., \& Horz H., Viruses versus bacterianovel approaches to phage therapy as a tool against multidrug-resistant pathogens. Journal of Antimicrobial Chemotherapy, 2014; $\quad$ 69(9):2326-2336 www.commons.lib.jmu.edu.

43. Bikard D, Euler CW, Jiang W, et al., Exploiting CRISPR-Cas nucleases to produce sequence-specific antimicrobials, Nat Biotechnol., $\quad 2014 ; \quad 32(11): 1146-50$. www.f1000research.com.

44. Ahmed K, Kaderbhai NN, Kaderbhai MA, Bacteriophage therapy revisited, African J Microbiol Res., 2012; 6:33663379. www.microbiology5.org.

45. Daria Vaisman, Studying anthrax in a Soviet-era lab - with Western funding, 2007. www.nytimes.com.

46. Carl R. Merril, Dean Scholl, Sankar L. Adhya, The prospect for bacteriophage therapy in Western medicine. Nature Reviews Drug Discovery, 2003; 2:489-97. 
47. McVay CS, Velásquez M, Fralick JA, Phage therapy of Pseudomonas aeruginosa infection in a mouse burn wound model, Antimicrob. Agents Chemother, 2007; 51(6):1934-8.

48. WBUR News, Scientists Engineer Viruses to Battle Bacteria, 2009; NPR 2018.

49. Vaiva Kazanavičiūtė, Audrius Misiūnas, Yuri Gleba et al., Plant-expressed bacteriophage lysins control pathogenic strains of Clostridium perfringens; Scientific Reports, 2018; 8:10589.

50. Qin Peng, Yihui Yuan, Characterization of a newly isolated phage infecting pathogenic Escherichia coli and analysis of its mosaic structural genes, Scientific Reports, 2018; 8:8086.

51. Li Ma, Sabrina I. Green, Barbara W. Trautner et al., Metals Enhance the Killing of Bacteria by Bacteriophage in Human Blood. Scientific Reports, 2018; 8:2326.

52. Sangjin Park, Soo Youn Jun, Chang-Hwan Kim et al., Characterization of the antibacterial properties of the recombinant phage endolysins AP50-31 and LysB4 as potent bactericidal agents against Bacillus anthracis, Scientific Reports, 2018; 8:18.

53. George V. Tetz, Kelly V. Ruggles, Hua Zhou, Adriana Heguy et al., Bacteriophages as potential new mammalian pathogens. Scientific Reports, 2017; 7:7043.

54. Pallavali RR, Degati VL, Lomada D, Reddy MC, Durbaka VRP, Isolation and in vitro evaluation of bacteriophages against MDR bacterial isolates from septic wound infections, PLoS ONE, 2017; 12(7):e0179245.

55. Hernández I, Bacteriophages against Serratia as Fish Spoilage Control Technology. Front. Microbiol., 2017; 8:449.

56. Duerkop BA, Huo W, Bhardwaj P, Palmer KL, Hooper LV, Molecular basis for lytic bacteriophage resistance in enterococci, mBio., 2016; 7(4):e01304-16.

57. Gundogdu A, Bolkvadze D, Kilic H, In vitro Effectiveness of Commercial Bacteriophage Cocktails on Diverse ExtendedSpectrum Beta-Lactamase Producing Escherichia coli Strains. Front. Microbiol., 2016; 7:1761.

58. Kusradze I, Karumidze N, Rigvava S, Dvalidze T et al., Characterization and Testing the Efficiency of Acinetobacter baumannii Phage vB-GEC_Ab-M-G7 as an Antibacterial Agent, Front. Microbiol., 2016; 7:1590.

59. Borysowski J, Weber-Dabrowska B, Górski A, Bacteriophage endolysins as a novel class of antibacterial agents. Experimental Biology and Medicine (Maywood, N.J.), 2006; 231(4):366-77. www.en.wikipedia.org.

60. Lee JH, Moore LD, Kumar S, Pritchard DG et al., Bacteriophage hyaluronidase effectively inhibits growth, migration and invasion by disrupting hyaluronan-mediated Erk1/2 activation and RhoA expression in human breast carcinoma cells, Cancer Lett, 2010; 298(2):238-49.

61. Lisa O'Sullivan, Colin Buttimer, Olivia McAuliffe, Declan Bolton, Aidan Coffey, Bacteriophage-based tools: recent advances and novel applications, F1000Research, F1000Research, 2016; 5(F1000 Faculty Rev):2782.

62. OJain P, Hartman TE, Eisenberg N, et al., 2012, fGFP10, a high-intensity fluorophage, enables detection and rapid drug susceptibility testing of Mycobacterium tuberculosis directly from sputum samples, J Clin Microbiol, 50(4):1362-9. www.f1000research.com.

63. Hodyra K, DaPbrowska K., Molecular and chemical engineering of bacteriophages for potential medical applications, Arch Immunol Ther Exp, 2015; 63:117-127.

64. Clark JR, March JB, Bacteriophages and biotechnology: vaccines, gene therapy and antibacterials. Trends in Biotechnol, 2006; 24: 212-18. www.microbiology5.org.

65. Vaks L, Benhar I., In vivo characteristics of targeted drugcarrying filamentous bacteriophage nanomedicines, J. Nanobiotechnology, 2011; 9:58.

66. Yacoby I, Bar H, Benhar I., Targeted drug-carrying bacteriophages as antibacterial nanomedicines, Antimicrob Agents Chemother, 2007; 51:2156-63.

67. Embleton ML, Nair SP, Heywood W et al., Development of a novel targeting system for lethal photosensitization of antibiotic-resistant strains of Staphylococcus aureus, Antimicrob Agents Chemother, 2005; 49:3690-6. www.jac.oxfordjournals.org.
68. Wang T, D'Souza GG, Bedi D, Fagbohun OA, Potturi LP, Papahadjopoulos-Sternberg B, Petrenko VA, and Torchilin VP, Enhanced binding and killing of target tumor cells by drug-loaded liposomes modified with tumor-specific phage fusion coat protein. Nanomedicine (Lond), 2010; 5(4):56374.

69. Bar H, Yacoby I, Benhar I, Killing cancer cells by targeted drug-carrying phage nanomedicines, BMC Biotechnol, 2008, 8:37.

70. Hosoya H, Dobroff AS, Driessen WH, et al., Integrated nanotechnology platform for tumor-targeted multimodal imaging and therapeutic cargo release, Proc Natl Acad Sci U S A, 2016; 113(7):1877-82.

71. Brasino M, Cha JN, Real-time femtomolar detection of cancer biomarkers from photoconjugated antibody-phage constructs, 2016; Analyst.

72. Barry MA, Dower WJ, Johnston SA., To ward cell-targeting gene therapy vectors: selection of cell-binding peptides from random peptide presenting phage libraries, Nat. Med, 1996; 2:299-305.

73. Qazi S, Miettinen HM, Wilkinson RA, et al., Programmed SelfAssembly of an Active P22-Cas9 Nanocarrier System, Mol Pharm, 2016; 13(3):1191-6.

74. Anders Lanzén, Addis Simachew, Amare Gessesse, Dominika Chmolowska, Inge Jonassen, Lise Øvreås, Surprising prokaryotic and eukaryotic diversity, community structure and biogeography of Ethiopian soda lakes, PLoS One, 2013; 8:e72577.

75. Leonardo Joaquim van Zyl, Shonisani Nemavhulani, James Cass, Donald Arthur Cowan, Marla Trindade, Three novel bacteriophages isolated from the East African Rift Valley soda lakes, Virology Journal, 2016; 13:204.

76. Getachew Belayneh, Azeb Tesfaye, Tsehaye Asmelash, Habtamu Taddle, Araya G. Therapeutic Potential of Bacteriophage Isolated From Sewage For Multidrug Resistant Escherichia Coli Infection In Mice.

77. Kiros Ashenafi, Gashaw Tadele, Teshale Ayichew, Phage Therapy; A Review on the Biology and Therapeutic Application of Bacteriophage, RC Journal of Animal and Veterinary Sciences (AJAVS), 2016; 2(4):15-25.

78. Belay Mulugeta, Sisay Tesfaye, Wolde Tesfaye, Bacteriophages and phage products: Applications in medicine and biotechnological industries, and general concerns. Scientific Research and Essays, 2018; 13(6):55-70.

79. Paul M, Ethiopia Commemorates the First Antibiotics Awareness Week. WHO Country Office - Ethiopia, 2015. www.afro.who.int.

80. Feleke Moges, Mengistu Endris, Andargachew Mulu, Belay Tessema et al., The growing challenges of antibacterial drug resistance in Ethiopia, Journal of Global Antimicrobial Resistant, 2014; 2(3):148-154. www.jgaronline.com.

81. Endrias Z, Prevalence, Distribution And Antimicrobial Resistance profile Of Salmonella Isolated From Food Items And Personnel In Addis Ababa, Ethiopia [MSc Thesis], 2004. www.etd.aau.edu.et.

82. Liyuwork Tesfaw1, Biruhalem Taye, Sefinew Alemu, Haile Alemayehu, Zufan Sisay and Haileleul Negussie, Prevalence and antimicrobial resistance profile of Salmonella isolates from dairy products in Addis Ababa, Ethiopia; African Journal of Microbiology Research, 2013; 7(43):5046-5050.

83. Andrzej Górski, Ryszard Mi edzybrodzki, Malgorzata Lobocka et al., Phage Therapy: What Have We Learned? Viruses, 2018; 10:288.

84. Nagel T.E., Chan, B.K, De Vos D, El-shibiny A, Kang'ethe EK, Makumi A, Pirnay JP, The developing world urgently needs phages to combat pathogenic bacteria, Front. Microbiol, 2016; 7:882.

85. Coker, A. O., Isokpehi, R. D., Thomas, B. N., Amisu, K. O., Obi, C. L., Human campylobacterios is in developing countries, Emerg. Infect. Dis, 2002; 8:237-244.

86. Ethiopian Investment Commission, Investing in Ethiopia: The future pharmaceutical hub of Africa, 2018; Pp. 1-15.

87. Available online: https://www.phagesforglobalhealth.org/ (accessed on 16 July 2018). 